\title{
Three key issues of urban renewal: Approaches for Turkey
}

\author{
Sevkiye Sence Turk*
}

\begin{abstract}
In many countries, urban policies and urban planning increasingly favor urban renewal more than new urban development. However, the urban renewal processes are challenging because of 'land assembly', 'recovery of urban infrastructure', and 'social sustainability. The success of the urban renewal processes is closely related to these three key issues because they can affect directly social, economic, and political costs and time periods. The aim of the article analyzes approaches and their outcomes for three keys issues faced in urban renewal processes in the Turkish case. Such an analysis offers insight into policies that can help to overcome three key issues faced in urban renewal and to promote sustainable urban renewal.
\end{abstract}

Keywords: urban renewal, land assembly, recover of urban infrastructure, social sustainability, Turkey.

\section{Introduction}

In most countries, urban policies and urban planning focus more on urban renewal than on the development of new areas. There are various reasons for this situation. The first of these reasons is that deterioration, collapse or lose of parts of the city over time (Zheng et al., 2014; Wang et al., 2014; Chan and Lee, 2008) and the need for the regeneration and development of these areas has arisen (Ho et al., 2012; Adams and Hasting, 2001). In the future, this need can be expected to increase even more. Because there has been a shift from a provider role of the state to a facilitator role of the state. As a result of such a shift, a tendency from determining a planning functions according to need and government finance to identifying functions financed by the market and defined by demand has occurred (Korthals Altes, 2014, p.78) With such a change, urban areas have become more open to the influence of market dynamics. As a matter of fact, in most urban areas, housing or office surpluses can be encountered (Heath, 2001). Since this surplus production in urban areas will turn into idle production over time, functional changes regarding the use of these areas are inevitable (Spaans et al., 2011). On the other hand, considering the size of the surplus production, it is clear that this transformation will not be easily achieved.

Second, most countries have adopted the urban sprawl prevention policy. Urban sprawl, destruction of open space and natural resources, increase in road and infrastructure costs, growth in vehicle traffic, etc. causes problems (Korthals Altes, 2007). Therefore, policy-makers try to control urban sprawl with brownfield development policies that encourage compact development. (Burchell and Mukherji, 2003). For example, in the Urban Task Force report published in the UK in 1999 , it is predicted that $55 \%$ of the houses produced in the UK between 1996-2021 will be placed on recycled land (Adams et al. 2001). That is, policy in the United Kingdom, policy favours 
development on brownfield rather than greenfields, in town rather out of town. Current planning thinking, driven by new imperatives of climate change, reducing carbon emissions and protecting habitat, is focussed more on higher housing densities, less car dependency, and compact cities (Home, 2009, p.106). Again, in 2008, a strategy for the development of urban areas instead of new urban development areas was determined in the European Urban Charter II. On the other hand, this trend changes in the opposite direction under pandemic conditions (Hamidi and Zandiatashbar, 2021). However, in this case, it is inevitable that the pressure for transformation on the outer periphery of the city will increase.

Third, in countries where neoliberal economic policies are adopted, the content of the intervention in urban areas has also changed with the restructuring of the state (Korthals Altes, 2014) along the lines of neoliberal principles. The tendency to rely on the private sector and publicprivate partnerships has increased, as states move away from the 'provider role' and take on the 'facilitator role' (Codecasa and Ponzini, 2011). This directly affects the forms of intervention in urban areas. Generally, the private sector tends towards demolishing and rebuilding (urban renewal), which is the most profitable form of intervention for itself, within different forms of intervention (repair, maintenance, restoration, protection etc.). (Gunay et al., 2015; Ho et al., 2012). In the urban renewal process, the private sector mostly prefers areas that will not cause problems for itself and maximize its profits.

The fourth is the incentive policy of the states to make urban areas attractive for investors. Mostly, states have started to follow various incentive policies to make urban areas attractive for both private and public-private sectors, depending on their changing roles. For example, encouraging land assembly (Turk and Demircioğlu, 2013), providing tax advantages (Adair et.al.2003), increasing development rights (Tarakçı and Turk, 2021a) etc. These incentives mean that the costs of the private sector decrease in urban renewal processes. Thus, urban areas have turned into attractive investment areas for the real estate sector. On the other hand, the increasing trend in land values after urban renewal projects caused an increase in exchange value in urban areas, and this has been an important factor for investors to turn to urban areas.

Despite the incentives for urban renewal in urban areas, key issues such as 'land assembly', 'cost recovery of urban infrastructure' and 'social sustainability' make urban renewal a challenge when compared to the development of new areas. Because these key issues often lead to prolongation of urban renewal processes (Home, 2007) and social, financial and even political costs. Therefore, approaches and results on key issues such as 'land assembly', 'cost recovery of urban infrastructure' and 'social sustainability' are critical in urban renewal practices. In this study, while 'land assembly' refers to the process of combining land to bring it to a suitable size for an urban renewal project, 'cost recovery of urban infrastructure' refers to the contribution of developer (or landowner) to the cost of urban infrastructure in urban renewal areas. Also, 'social sustainability is defined based on social capital, social infrastructure, social justice, and equity, and governance in urban renewal areas.

The aim of this article is to systematically analyse the different approaches that emerged for these three key issues in urban renewal practices and the results of this approach, in the case of Turkey.

There are some features that make the Turkish example a good laboratory in the examination of this subject. The first of these is the intense use and discussion of urban renewal in Turkey since the early 2000s. There has been a serious urban renewal practice in the last 20 years. In particular, the most intense area of discussion in terms of urban renewal practices is Istanbul, due to its sensitive geography because of its natural features like having catchment areas, being exposed to 
earthquake threat, etc. (Türkün, 2014). Second, in urban renewal processes; different approaches have been experienced in sense of these three key issues. However, these approaches and their results have not been adequately evaluated in a systematic way. Third, urban renewal areas in Turkey mostly cover informal settlement areas. These areas show quite complex features due to their different tenure structures (Kuyucu and Ünsal, 2010). This makes solving three key problems in urban renewal projects more challenging. The findings to be obtained with the article can shed light on policies that can help different countries to overcome these three key issues that are commonly encountered in urban renewal processes.

In the second part of the article following the introduction, international approaches, trends and results regarding three key issues of urban renewal are examined. In the third part of the article, general characteristics of urban renewal practices in Turkey are given. In the fourth chapter, the approaches followed in Turkey for three key issues and their results are given. The fifth part of the article is devoted to general evaluation and conclusion.

\section{Three Key Issues of Urban Renewal}

As one of three key issues in urban renewal, land assembly is both complex and costly. Today, public and private land developers in many countries commonly describe the process of land assembly as conflict-ridden and the associated problems as intractable (Heller and Hills, 2008; Hong and Needham, 2007; Home, 2007). Mostly, fragmented and clumsy landownership structures prevent successful and efficient urban renewal projects. In a common manner, two fundamental tools are intensively being used as land assembly methods of urban renewal in various countries. The first one is renewal via either expropriation or compulsory purchase methods, and the second is ways of renewal depending on the purchasing of the real estate by developers or the public (Turk and Korthals Altes, 2010). Expropriation is a way effectively overcoming 'ownership constraints' (Adams et al., 2001), especially in urban renewal projects. Although the powers to expropriate land exist in most nations of world (Alterman, 2010), there are differences in the legal conditions and practical constraints among countries (Alterman, 2007). These differences can appear in using of expropriation for urban renewal. For example, the interpretation of 'public interest' can differentiate according to the legal conditions of the countries. In some countries, the narrowing range of 'public interest' for which land may be taken are accepted. For example in Israel, there are greater restrictions than in the past on the range of 'public interest' for which property may be expropriated and especially on the reuse of the land once the original use is no longer necessary (Alterman, 2007). In other countries where the broadening range of 'public interest' are basic, compulsory acquisition may be used to achieve efficiency in the production of good and services, both public and private; balancing economic, social and cultural benefits, and ensuring environmental balance and guiding development and redevelopment of land to more desirable purposes (Larbi et al. 2004). For example, at the beginning of 20th century in the Netherlands, the public interest was defined in broad way. 'The public interest' served not only by the compulsory purchase of blighted areas, but also by the development of new housing areas to accommodate social housing. That is, the justification of compulsory purchase in blighted areas depended on the development of the new housing areas to accommodate social housing (Korthals Altes, 2014, p.79).

On the other hand, the interpretation of 'public interest' in the using of expropriation in urban renewal projects has been affected by the neoliberal ideas focussing on 'state-mediated market rule' (Fox-Rogers and Murphy, 2015; Peck and Tickell, 2002). For example, in the Kelo case, the US Supreme Court on 23 June 2005 upheld the government's use of expropriation to assemble land in a redevelopment area and transfer it to another private party as part of a larger private economic development project (Carpenter and Ross, 2009; Jacobs and Bassett, 2011). With the 'Kelo 'case, 
the ruling grants governments a carte blanche for the compulsory transfer of private property from ordinary citizens to politically powerful real estate entrepreneurs (Lehavi and Licht, 2007, p. 14). Following the ruling, a majority of states enacted legislation to limit the power of expropriation for economic development and to put other restrictions on assembling land for major redevelopment projects. Also, this ruling reveals that the conditions under which expropriation is allowed tend to be based on jurisdiction-specific particularities (Van Stalen and Korthals Altes, 2016). Expropriation is no longer considered as useful an instrument in the past assembling land because of reasons like the emergence of new public needs, blurring in distinction between public and private (Alterman, 2007).

Beyond the legal constraints, there are practical constraints in using of expropriation for urban renewal. First is related to the outcomes of expropriation. Expropriation has result in adverse socioeconomic consequences including landlessness, loss of livelihood heightened tension in state and community relationship (Larbi et al. 2004). In USA, urban renewal areas that used expropriation reveals are disproportionately populated by those who are poor, minority and less educated (Carpenter and Ross, 2009). Second is that local governments have to pay compensation for properties in expropriation. Generally, the compensation value based on market value of the property under the original land use decision. In some countries, the compensation can include collateral costs caused by expropriation process like migration costs, reduced revenue and detriment from abolished leasing contracts (Šumrada et al. 2013, p.19) Therefore, local governments cannot meet from the budgets financially. Third is that expropriation procedures tend to be long duration. This will mean that in many cases, expropriations will be more expensive and time-consuming, as they will imply longer consultation proceedings and their success will depend on issues that have nothing to do with property rights (Azuela and Herrara Martin, 2009, p. 358).

In some countries, using of expropriation in urban renewal can serve as a big stick to force private parties to comply. For this, the governments may have chosen not to use expropriation, they prefer to reach compromises. In the Netherlands, for example, self- realisation principle can help to negotiate a deal. If land owners are willing and able to implement the plan themselves and they present to the local authorities with serious plan, the land cannot be acquired compulsorily (Korthals Altes, 2014).

On the other hand, expropriation is viewed as a solution for prevention of holdout problem. The method of purchasing real estate in inner city areas by developers or public authority is completely carried out within the framework of private law principles and market mechanisms. In use of purchasing, assembly of properties by market parties may however encounter a hold-out problem, caused by the phenomenon that acquiring the last plot of land necessary for development has a higher value to the buyer than earlier acquired plots, all of which raise the costs of redevelopment (Miceli and Sirmans, 2007; Turk and Korthals Altes, 2010; Turk and Demircioglu, 2013). The situation can result in delays or can require the rearrangement of the project by removing the parcels causing problems (Adams et al., 2001). In Israel, the use of expropriation for holdout problem would encounter the same lengthy and costly procedure as encountered in expropriation generally (Alterman, 2007, p.74).

One other of key factors is the recovery of urban infrastructure costs. Urban infrastructure for urban renewal areas can be defined as essential services that residents cannot do without. The provision of urban infrastructure in urban renewal areas includes the improvement of the accessibility of the area by connecting it to transport networks, the improvement of the quality of public space (Verhage, 2005, p. 219), the improvement of 'hard' infrastructure such as electricity, gas and water supply, sewage disposal, and telecommunications, and improvement of 'soft' 
infrastructure such as community centres, schools, recreation facilities and green space (Graham, 2000; Ennis, 2003). While the provision of urban infrastructure in urban renewal areas directly affects the well-being of residents, it triggers an upward spiral of revaluation and regeneration in those areas (Verhage, 2005). This creates attractiveness for business and residents. However, the costs of servicing land are mostly higher for urban renewal areas than they are for new urban developments. Mostly, it becomes difficult to meet these costs with potential profits in urban renewal areas (Van der Krabben and Needham, 2008). This situation requires the financial support of the state. However, it no longer seems easy to provide the financial support from the state for urban infrastructure. After the 1980s, with the adoption of a neo-liberal context, the policy in delivery of urban infrastructure and the role of state within this policy changed (Ingram and Hong, 2012). As a general tendency, governments decreased their financial backing of infrastructure work, motivated by political thinking on 'value for money', and risk transfer away from the public sector, budget constraints, and needs for capital improvements (Torrance, 2008, p. 2). In cities, trends towards liberalisation and privatisation in urban infrastructure delivery have recently accelerated and the responsibility to the state, the ownership of and responsibility for urban infrastructure have changed. This has resulted in the 'splintering' of integrated urban networks (Graham and Marvin, 2000). There has been a general shift away from standardised and territorially integrated infrastructures to ones that are more fragmented and spatially differentiated (Moss, 2008, p. 438). Mostly, the provision of urban infrastructure has been shown to be dependent on the ability of planning authorities to negotiate the delivery of infrastructure with the delivery providers (Ennis, 2003) to secure sufficient financing for necessary infrastructure projects (Webber and Marshall, 2007).

Another key factors in urban renewal projects is the provision of 'social sustainability'. A 'social dimension' to urban renewal has been mostly neglected or the strength and positioning of this changed depending on the perspective adopted (Colantonio and Dixon, 2011). Various problems can appear in urban renewal projects that can affect the social sustainability. First is the gentrification and displacement of local residents and activities (Lees et al., 2015). The second is the exacerbation of social exclusion of particular groups within local communities (Steen, 2004; Murie and Musterd, 2004). The third is the ignoring of resident's participation. Mostly, urban renewal practices tend to be basically profit oriented and consider housing a commodity for the open market. Such projects are mostly exploited ad a means of profit making by developers rather than as an opportunity to improve a community through dynamics and resident's participation ( $\mathrm{Ha}$, 2001; Parés et al., 2014). The fourth one is the disregarding of social capital within local communities (Parés et al., 2014). Social capital takes time to develop and is inherently nontransferable $(\mathrm{Ha}, 2004)$. The fifth one is the problem related to the provision of social housing in urban renewal areas. Traditional urban renewal processes relied on the financial support of central or local governments for recovering costs related to social housing. However, the support of the state has a declining tendency (Turk and Korthals Altes, 2013). Most projects tend to be in the form of expensive, profit generating residences based on owner-occupation for middle and upper income groups or for commercial use (Shin, 2009). This means that the provision of social housing remains insufficient in urban renewal projects. The sixth one is the condition of residents who are in a vulnerable position such as tenants or informal users (Korthals Altes, 2016). Urban renewal may result in the dislocation of these groups.

\section{Main Features of Turkish Urban Renewal Practices}

\section{Urban renewal practices until 2012}

In Turkey, after the earthquakes in 1999, the low quality of the existing residence stock in the cities, the ageing urban structure and the zones where important geotechnical risks are available 
have become much more important, and urban renewal came to the fore as an option to mitigate the risk posed by earthquakes in these areas. The highest land prices in inner city areas and an increase in the unearned income in these areas have led to making urban renewal more attractive (Özden, 2016). With the 'housing oriented construction' policy adopted by the government (Balaban, 2012), a construction boom occurred by increasing investment pressure on inner city areas, and these areas became important investment areas for the real estate sector (Karaman, 2013; Şen and Türkmen, 2014) by beginning an era when the exchange value of inner city areas increased (Dinçer, 2011; Türkün and Öktem, 2014). During this term, the state's role in creating and operating the market was restructured (Şen and Türkmen, 2014, p. 184).

Until Law No. 6306 came into force in 2012, an important urban renewal experience had emerged, particularly in Istanbul. This experience has some features. The first of them is the fact that urban renewal project areas are mostly located in inner city areas and squatter housing areas close to the centre (Türkün, 2014). Mostly, these areas are subjected to a complicated ownership structure. There are de jure ownerships, de facto use rights and occupiers who have no de jure ownership in urban renewal areas (Kuyucu and Unsal, 2010). The second feature is that main actors are TOKI (Housing Development Administration), local authorities (Eraydın and Taşan-Kok, 2013; Kuyucu, 2018), large-scale companies in the urban renewal practice (Tarakcı and Turk, 2021). In urban renewal projects, mostly local, the central government enter into public-private sector joint ventures with large-scale companies. In this partnership, the main role of the public is to facilitate land assembly and to evacuate the land and making it ready for the urban renewal project. Therefore, urban renewal projects are initiated by the public sector. In this partnership, capital is supplied by the large-scale companies (Ozkan and Turk, 2015). A third feature is mostly the adoption of an 'in situ transformation' approach, meaning that landowners remain on the land after the urban renewal project is completed (Unsal and Turk, 2014). In these projects, landowners were given housing units from urban renewal areas in exchange for their own places. However, it is mostly these landowners who sold the units they bought from urban renewal projects and moved to other areas in the city. Urban renewal projects are only focused on physical and demographic upgrading rather than improving the living conditions of existing inhabitants, this can result in a process of property transfer and displacement (Kuyucu and Unsal, 2010; Dinçer, 2011; Türkün, 2014; Özkan and Turk, 2015). The fourth feature is that most urban renewal projects target producing market housing for sale focused on profit driven and income generating for high-income groups (Tarakcı and Turk, 2021a, b forthcoming).

\section{After 2012 Urban renewal practices}

After Law No. 6306 came into force in 2012, both single building scale and area scale urban renewal has started to be implemented. While the law encourages renewal at the single building scale with the concept of risky building, it also encourages renewal at the area scale with the concept of risky area (Gür and Turk, 2014). However, renewal on a single building scale has gained a significant momentum and its effects on urban development, planning and the housing market have increased. Istanbul has been the place where renewal on a single building scale was experienced intensively (Kısar Koramaz et al. 2018). There are important differences between the renewal dynamics at the area scale and the renewal dynamics at the single parcel scale both in terms of actors and results. In a risky structure, the process starts with the application of the owner, but the process in the risky area must be determined by the Ministry. This differentiation affects the process in terms of speed (Tarakçı and Turk, 2021a). In the single building scale renewal, risky buildings are demolished and statically more durable structures are built in their place, but there is no regulation regarding the surrounding or urban planning (Tarakçı and Turk, 2021a, Kısar Koramaz et al.,2018). For example, if there is a problem of insufficient green space and parking in the area 
where the risky building is located, the single building renewal does not produce any solution to these problems and does not make any contribution to urban planning.

According to Law No. 6306, the work process of renewal starts with identifying the area as a risky area, continuing with the land development process, and ending with the completion of construction and the start of everyday life in the area. The developer and the Ministry of the Environment and Urbanization (central government) are the main actors in the process. Although TOKI became the main actor of transformation with the law no. 5162 enacted in 2004, the Ministry of Environment and Urbanization has wide powers in this regard since 2012. With the inclusion of TOKI in the Ministry of Environment and Urbanization within the scope of the Decree Law No. 703 in 2018, the powers of the Ministry were further strengthened. Even though the public initiated the process in the first place, the number of individual applications for risky buildings has been increasing in many parts of the cities after 2015, and the public is withdrawing step by step from transformation applications. The Ministry is the primary decision maker, and the developer bears all costs. The landowner is involved in the process of signing an agreement with the developer and is not included until the new building is given to him/her (Tarakçı and Turk, 2021a). According to Law No. 6306, the criteria for identifying risky areas have not been determined in concrete terms, but are left to the discretion of the administration. Article 5 of the Law No. 6306 sets outs some criteria in this regard. For example, "Technical report stating that the area has the risk of causing loss of life and property due to ground structure or construction on it" is sought for risky area determination. However, criteria such as "Places where public order or security is disrupted in such a way stopping or interrupting the ordinary course of life, ... Damage to infrastructure or superstructure, ..." contain uncertainty and arbitrariness. It can be said that criteria have not been determined clearly.

Thus, while determining the boundaries of urban renewal areas, purely scientific data are not used (Kuyucu, 2018; Turk and Ozcivan, 2017; Tarakcı and Turk, 2015; Güzey, 2016). According to Law No. 6306, in order to be a risky area, there should be a problem either in the ground structure or in the case of construction on it. However, the soil structure is not risky, and many areas are declared as risky areas without the individual buildings being analyzed. For this reason, lawsuits are filed by the rights holders or non-governmental organizations for the cancellation of the risky area decision in many places where the risky area is declared (Tarakcı and Turk, 2015).

\section{Approaches for Turkey and their outcomes}

\subsection{Land Assembly}

'Land assembly' refers to the process of combining the land to bring it to a suitable size for the urban renewal project. Land assembly contains changes in landownership through acquisition of the necessary parcels of land to make property development and infrastructure provisions possible (Louw, 2008) The existence of a number of small parcels, fragmented ownership structure problems and illegal uses in urban areas make the use of purchase difficult for a developer (or land owners) and public authorities in urban renewal (Turk and Korthals Altes, 2010). The urban areas make the use of purchase difficult for a developer (or a land owner) in Turkey, and constraints in land supply for large size plots make hold out problems more severe in urban areas. So, developers (or land owners) often face delays or increase costs in the project. An active public role might not be preferred in land assembly due to the changes in public opinions as well as increasing costs. From the perspective of the Ministry, the Ministry does not directly use its expropriation authority in terms of increasing costs. Instead, the Ministry uses its expropriation authority to persuade landowners who do not have an agreement to agree. In terms of local governments, there are two 
reasons why local governments prefer not to use expropriation for land assembly in urban areas. First is that the local governments have inadequate funds to begin expropriation. Most municipalities do not have sufficient financial sources for providing serviced urban plots. Second is that expropriation can cause delay, because if the compensation is low or the process is faulty, the landowners can take legal action. In case the landowners take legal action, it can result in both elongation of the process and an increase in cost.

However, after 2005 with Law Nos. 5393 and 5366, in renewal areas during the land assembly, the municipality has the right to make agreements with the landowners, and if there is no agreement it has expropriation authority. Here, the logic in the laws is the use of expropriation as a threat (a stick) more than a direct tool. However, this type of using has some problems. One of them is to be determined the compensation payment. The payment is quite low. The resettlement costs are not included in the compensation of the expropriation and mostly, the tenants are not taken into consideration. Another problem is to be used the expropriation for private development without the production of social housing (Turk and Korthals, 2010). When Law No. 6306 came into force in 2012, the government started an expediment for resettlement in order to clear the residential areas that are at risk of causing loss of life and property from unsafe and unhealthy structures and to reconstruct them in a disaster-sensitive manner (URL-1). The rapid production of new housing areas against disasters was considered public interest. At this point, it was not taken into consideration whether the houses produced were social housing or not. In this case, it is seen that the public interest is handled very broadly in urban renewal.

Law No. 6306 facilitates this land assembly. Land assembly depends directly on the landowner's request and behavior. The landowners behave with this approach by maximizing their continuous earnings, having many options to decide on a developer. Therefore, it is not possible to finalize negotiations in a short time. The developers were faced with the problem of hold-outs. Under these circumstances, the Ministry stepped in by implementing the "two-thirds (2/3) majority rule" to ensure land assembly under Law No. 6306 by using public power (Ocakçı et al., 2017). In areas not covered by Law No. 6306, the land assembly is realized with the request and consent of all right holders. However, in an urban renewal area, a 2/3 majority of landowners can decide on which developer to make agreements with. However, the fact that the Ministry stepped in to help accomplish land assembly for urban renewal purposes strengthens the hand of the developers who have undertaken the projects for these plots, while weakening that of the landowners. Landowners who could not be previously convinced are forced to make a deal with the developers. Demolition starts when these agreements are completed.

There are some objections related to the necessity of a majority of two-thirds of the shareholders participating in the shared property proposed by law (Özsunay, 2015). Such interventions aim at accelerating the process. However, the problematic issue here is that the shareholders not agreeing with the majority are forced to sell their shares to the other shareholders. They may have to sell not only to other shareholders, but also to the public. The law gives this task to the public if other stakeholders do not take it. Another issue is whether the public is strong enough to buy every real estate that other stakeholders have not bought or not, and what will happen to these properties if the public does not buy them. On the other hand, this situation is contrary to the provisions of the constitution and Turkish Civil Law. For the one-third (1/3) of shareholders that are forced to sell under the law are not granted the right to purchase the twothirds of the shareholders' share. The Turkish Civil Law, however, regulates how a partnership among shareholders may be dissolved. Here, all shareholders and third persons are entitled to participate in the sale. Such an approach is considered a new approach in the Turkish legal system (Kürşat, 2013). 
As in many other countries, the property right is protected by the constitution in Turkey. For this reason, intervention in ownership and violating the right to property must involve severe conditions. In spite of this fact, the shares of the minority not joining the two-thirds majority are subject to intervention without any obligation and court decision, and the shareholders in question are forced to sell their shares. By this aspect the law constitutes a violation of the constitution by being in the nature of a disproportionate intervention in the right of property (Kürşat, 2013, p. 46). In cases where a minimum majority of two-thirds is not reached between the landowners of a land on which a building was demolished, private properties are immediately expropriated by the Ministry. Such expropriations are considered as 'expropriation for housing' under Law No. 6306. According to decisions of the Constitutional Court (02.27.2014, E: 2012/87 K: 2014/41), there is public interest on the expropriation of properties as part of the rearrangement of the housing status of settlements under the risk of disaster.

Turkey has had a long tradition of using land readjustment (LR) and currently, implemented both in built-up and new development areas. The method is now frequently used in new development areas of the city. In Turkey, the distribution in the LR process is only provided in the form of land, not on the value base. However, in recent years, there were some examples that LR was implemented in urban renewal areas. One of these examples is the Ayazma Urban Renewal Project (Turk, 2014). In this project, LR is used to assembly land. After $L R$, in the urban renewal area, the average parcel size has increased from $6,830.09 \mathrm{~m} 2$ to $9,187.1 \mathrm{~m} 2$. The average number of landowners per parcel has also increased from 4.9 to 7.9 (Turk, 2014). The result of the project demonstrates that LR is used for land assembly. Although the land assembly is provided, the number of landowners per parcel has increased. In this condition, after LR the serviced urban plots produced remain in a joint ownership structure. Construction works on the urban plots with joint ownership structure or sale of these plots are only possible with the participation of all owners (Turk, 2014). For this reason, it is evident that LR later requested will not occur in a short time. However, it is possible that the difficulty can be overcome with densification. For example, the owners can take housing units in return for their own shares of large parcels for mass housing. In this project, development rights in the urban renewal area are defined quite flexibly, allowing for production of a large number of residences. In this case the owners of properties divided into shares can get residence units in return for their shares (Turk and Demircioglu, 2013).

Another method for land assembly in Turkey is using market-led measures for land assembly. This type of land assembly is implemented through Plan Notes. Plan notes are prepared based on local spatial plans. In terms of legal processes, plan notes give information in detail and clarify unexplained issues above plans. Over time the scope has expanded. Plan notes define variations such as mixed and optional land-use functions, or development with a preliminary project. Additionally, they include regulations concerning urban infrastructure or land assembly (Turk, 2018). For example, in Fikirtepe urban renewal project, plan notes were used to provide land assembly. According to the plan notes, the floor area ratio (FAR) is calculated over the gross parcel area. The roads remaining within the block sites, which are closed, are not included in the floor area ratio. In parcels that are assembled to form a block site, the floor area ratio is 4.00 with a $100 \%$ increase. $25 \%$ of a block site is set aside for social and technical infrastructure areas. With the plan, the development rights in the area have been doubled and the urban renewal projects in the area have been made attractive for the private sector and property owners. In response to these increases, a 25\% deduction was made from the land owners' lands (Tarakçı and Turk, 2021a; Tarakçı and Turk, 2021 forthcoming; Turk et al., 2020). 


\subsection{Recovery of urban infrastructure costs}

Recovery of urban infrastructure costs refers to the contribution of developer (or landowner) to the cost of urban infrastructure. In urban renewal areas, landowners generally participate in (onsite) costs, while off-site costs do not. However, the methods for covering urban infrastructure costs in urban renewal projects may also differ. According to Law No. 5366, which entered into force in 2005, land owners in urban renewal areas can prepare business projects related to social infrastructure and facilities, common areas, conditions of use and utilization of social facilities and services, and methods of participation in costs. The law takes into account the costs for the project area. However, the main roads and main infrastructure that the area benefits from are not taken into account.

Again, in the law numbered 5998, which entered into force in 2010, infrastructure and recreation expenses are counted as project common expenses. Construction permit and occupancy permit cannot be issued before the project common cost is paid. Here, too, only infrastructure and recreation expenditures for the project area are taken into account.

In the Law No.6306, no detailed explanation was given regarding the payment of infrastructure costs. This situation is mostly resolved with plan notes. For example; In Fikirtepe Urban Renewal Project, plan notes were used. On the one hand, land contribution is foreseen for social and technical infrastructure areas. The plan notes state that in the areas designated as residential, trade and trade-residential areas, a public service area shall be marked off of up to $25 \%$ of the total net parcel area. However, there was uncertainty concerning the location and nature of social and technical infrastructure areas once the plan note was applied. These areas were subsequently determined by negotiations between the developer and the Ministry during the construction permit process (Tarakçı ve Turk, 2021a). On the other hand, apart from the land contribution, it is foreseen to receive the "Infrastructure Participation Fee" with the plan notes. The Plan Notes states that all road and infrastructure costs would be paid by the landowners or the developer to the Istanbul Metropolitan Municipality. It was determined that the infrastructure participation fee would be paid by the developer. Again in the plan note, it is stated that this Infrastructure Participation Fee must be paid at the construction permit stage. Determination of Infrastructure Participation Fee by the plan notes creates uncertainty about whether this fee can be used in other urban renewal areas, or not. Other uncertainty is also related to where the collected fee is used directly (Tarakçı ve Turk, 2021 b, forthcoming).

\subsection{Social sustainability}

According to Murphy (2012), social sustainability is based on a four-principle division of social sustainability, namely: equity, participation, social cohesion, and public awareness. Cuthill (2010) defines that social capital, social infrastructure, social justice and equity, and governance are the key concepts of social sustainability.

In renewal areas, landowners are given new housing units on the project area in exchange for their own places. In cases where the property of the landowner does not meet the price of the new flat or where the landowner demands a larger residence unit, the difference is provided through the long-term debiting of the landowner. Involvement of landowners in the process targets facilitating land assembly rather than protection of social capital or ensuring social cohesion or social mixing (Turk and Korthals Altes, 2013). Regulations in the legal structure define how landowners will benefit from the opportunities offered by the projects and do not allow any interventions that cause the project to stop or change (Şen and Türkmen, 2014, p. 170). 
In urban renewal, there must be a process that allows the participation of all residents. For this, first of all, the first condition is that the residents of a place are offered options that they can evaluate so that they can decide on the accommodation and working conditions by participating in the urban renewal process. The second condition is that the actors are equipped to negotiate these options and have the power to bear the economic obligations. Third, they must have full knowledge of the process and the ability to organize in order to influence the urban renewal process (Gümüşbağ, 2009, p. 35). However, there is no process that allows the participation of all residents in the urban renewal projects. Participation in urban renewal goes through property ownership (Ozcivan, 2016). In this case, while the participation of the land owners in the urban renewal is ensured, this does not apply to those who have a certificate of occupancy (tapu tahsis documents) and the 'occupiers'. In other words, land owners, owners of the occupancy certificates and occupiers take part in urban renewal depending on the degree of ownership in the settlement process (Ozcivan, 2016). Generally, those with a certificate of occupancy (tapu tahsis documents) are given demolition payment for the squatter housing on their parcels. Mostly, affordable housing units with long-term payment outside the project area are provided in exchange for demolition payment and certificate of occupancy. While those with a certificate of occupancy have sometimes been moved to remote areas in the peripheries of cities, sometimes they have been sent to areas closer to the project areas. For instance in Istanbul, under the Sulukule Urban Renewal Project, inhabitants were moved to Taşoluk that is located $40 \mathrm{~km}$ away (Islam and Enlil, 2010) while under the Ayazma Urban Renewal Project those with a certificate of occupancy were sent to the Bezirganbahçe Mass Housing Area that is closer The main problem for those sent to remote areas is that commuting to work in city centres or the possibility of finding new jobs is eliminated (Türkün, 2014). The basic problem for those moved to closer areas is the difficulty in paying the instalments for the houses. In other words, they are unable to meet the cost of living in their new environments (Türkün, 2014). On the other hand, tenants are the most aggrieved among those groups (Karaman, 2013; Kuyucu, 2013). In such areas, landowners living outside the urban renewal area support urban renewal projects and participate in them because of expecting an increase in the value of their properties following urban renewal. In this case, tenants living in the area have no option other than leaving the area. Although in some cases tenants are also offered affordable housing units subject to long-term repayment, they face severe payment problems (Islam and Enlil, 2010, p. 319).

Urban renewal causes gentrification. Important rise in prices occurs in urban renewal areas, which gives rise to a high rent gap. The development rights of the new local spatial plan have the greatest impact on land values. The higher the development rights in the plan, the higher the value increase in the area. Besides, the expectation that projects will target high-income groups postrenewal also affects the value of the land (Tarakçı and Turk, 2021a). For example, an average $\mathrm{m} 2$ value of 800-900 USD was paid during expropriation in the Tarlabaşı urban renewal area. However, the $\mathrm{m} 2$ sale value of the buildings that resulted from the project was 7,500 USD (Türkün and Sarıoglu, 2014). For this reason, only high-income groups are able to enter the area following urban renewal while it is not possible for those with a certificate of occupancy, tenants and occupants living in the area prior to the project, to return to the area following urban renewal. On the other hand, most of the landowners remaining in the area following urban renewal have failed to sustain their lives there due to increasing costs. Landowners prefer to sell their properties, taking advantage of the rent gap in order to purchase housing units in locations which are better suited to their conditions (Güzey, 2016). Most urban renewal projects target producing market housing for sale focused on profit driven and income generating for high-income groups. In other words, urban renewal projects only ensure the physical development of the area while in many instances ignoring economic and social development. Such a tendency prevents all income groups from living in the area (Türkün, 2014). For example, tenants who have lived in the urban renewal area for many years 
are not likely to return to the area after the project. Most of the time, it is predicted that a new social group will live in the area after the project. Such an approach shows that social capital is not taken into account.

\section{General Evaluation and Conclusion}

At the both international and national contexts, the urban renewal processes are challenging because of 'land assembly', 'recovery of urban infrastructure' and 'social sustainability'. The success of the urban renewal processes is closely related to these three key issues because they can affect directly social, economic and political costs and time period. In this article, the different approaches that emerged for these three key issues in urban renewal practices and the results of this approach, in the case of Turkey are analysed.

In Turkey, different approaches related to the land assembly, cost recovery of urban infrastructure, and social sustainability have been experienced. In land assembly, in Turkey, the traditional methods (purchasing or expropriation) might not be preferred due to the changes in public opinions as well as increasing costs by neither central government nor local governments. The public institutions trust on the developer or landowners on land assembly. With Law no. 6306, the central government seem to facilitate this land assembly in the favour of developers with "twothirds (2/3) majority rule". However, the law constitutes a violation of the constitution by being in the nature of a disproportionate intervention in the right of property. In this case, it is inevitable for one-third (1/3) of shareholders that are forced to sell to go the litigation process. On the other hand, land readjustment and plan notes can be used for land assembly instead of expropriation. The use of these vehicles is mostly shaped on the tendency to increase the density. This situation is also not sustainable. Again, although there is legal flexibility in the use of plan notes in urban renewal, it also reveals uncertainty in the process. This in turn increases the social and financial costs of land assembly.

On the other hand, in the urban renewal laws that came into force since 2004, the contribution of the developers or land owners into urban infrastructure costs in urban renewal areas is given very limited or not at all. In practice, the contribution into urban infrastructure costs has been resolved with plan notes. However, since no legal base is defined, it creates uncertainty in terms of other urban renewal areas. At the same time, it also creates uncertainty about how this collected fee will be used. Also, this uncertainty directly affects the determination of urban infrastructure, site selection and construction. Both land assembly and cost recovery of urban infrastructure requires both legal and institutional certainties for all sides. However, the legal power of the plan notes is weak when compared to other methods (Turk, 2018).

In renewal projects, the protection of social capital or ensuring social cohesion or social mixing is neither defined in legal instruments, nor is there any practice about it. Besides, there is no process that allows the participation of all residents in the urban renewal projects. Participation in urban renewal projects is shaped as depending on property ownership. While the participation of the land owners in the urban renewal is ensured, this does not apply to those who have a certificate of occupancy (tapu tahsis documents) and the 'occupiers'. Tenants have not been taken into consideration. Most urban renewal projects target producing market housing for sale focused on profit driven and income generating for high-income groups. Therefore, urban renewal projects cause gentrification because of a high rent gap. While high land values let high-income groups to enter the area following urban renewal, such a tendency prevents all income groups from living in the area. This situation means not to protect social capital. Besides, disregarding social 
sustainability and focusing only on physical renewal means moving problems away rather than solving them. It is clear that urban renewal cannot be done in spite of people.

The findings of the article demonstrate the critical significance of the approaches related to the land assembly, cost recovery of urban infrastructure, and social sustainability in urban renewal processes. The solution of these three key issues is only possible with a holistic perspective. It is clear that urban renewal projects cannot be successful unless a holistic and strong policy is developed for these three key factors.

\section{References}

Adair, A., Berry, B., McGreal, S. (2003) Financing Property's Contribution to Regeneration, Urban Studies, 40 $(5-6), 1065-1080$.

Adams, D., Disberry, A., Hutchison, N., \& Munjoma, T. (2001). Ownership constraints to brownfield redevelopment. Environment and Planning A,33(3), 453-477.

Adams, D., Hastings, E.M. (2001) Urban Renewal in Hong Kong: Transition from Development Corporation to Renewal Authority, Land Use Policy, 18, 245-258.

Alterman R. (2010), Takings International: A Comparative Perspective on Land Use Regulations and Compensation Rights, Chicago: American Bar Association Publications.

Alterman, R. (2007), More than land assembly: Land readjustment for supply of urban public services, In YuHung Hong \& B. Needham, Analyzing land readjustment: Economics, law, and collective action, pp. 5788, Lincoln Institute of Land Policy, Cambridge, Massachusetts.

Azuela, A., Herrera-Martin (2009) Taking Land Around the World: International Trends in Expropriation for Urban and Infrastructure Projects, In: Somik V. Lall, Mila Freire, Belinda Yuen, Robin Rajack, Jean-Jacques Helluin (Eds.), Urban Land Markets, p.337-362, Springer.

Balaban, O. (2012) The negative effects of construction boom on urban planning and environment in Turkey: Unravelling the role of the public sector. Habitat International, 36, 26- 35.

Burchell R.W., Mukherji S. (2003) Conventional Development Versus Managed Growth: The Costs of Sprawl, American Journal of Public Health, 91 (9), 1534-1540

Carpenter, D. M., Ross, J. K. (2009) Testing O'Connor and Thomas: does the use of eminent domain target poor and minority communities?, Urban Studies, 46(11), pp. 2447-2461.

Chan, E.H.W., Lee, G.K.L. (2008) Critical factors for improving social sustainability of urban renewal projects, Social Indicators Research, 85(2),243-256.

Clark, G.L. (2005) Setting the agenda: the geography of global finance, School of Gegraphy and the Environment Working Paper Series WP 05-03, Oxford.

Colantonio, A., Dixon, T. (2011) Urban Regeneration and Social Sustainability: Best Practice from European Cities, ISBN: 978-1-405-19419-8.

Codecasa, G., Ponzini, D. (2011) Public-Private Partnership: A Delusion for Urban Regeneration? Evidence from Italy, European Planning Studies, 19(4),648-667.

Cuthill, M. (2010). Strengthening the 'social' in sustainable development: Developing a conceptual framework for social sustainability in a rapid urban growth region in Australia. Sustainable Development, 18(6), 362373.

Dinçer, i. (2011) The Impact of Neoliberal Policies on Historic Urban Space: Areas of Urban Renewal in Istanbul, International Planning Studies, 16 (1), 43-60.

Ennis, F. (2003) Infrastructure Provision and Negotiating Process, England, Ashgate Publishing Limited.

Eraydin, A., Taşan-Kok, T. (2013) State response to contemporary urban movements in Turkey: A critical overview of state entrepreneurialism and authoritarian interventions, Antipode, 46 (1), 110-129.

Fox-Rogers, L., Murphy, E. (2015) From brown envelopes to community benefits: The co-option of planning gain agreements under deepening neoliberalism, Geoforum, 67, 41-50

Graham, S. (2000) Cities and Infrastructure Networks, International Journal of Urban and Regional Research, $24(1), 114-119$.

Graham, S., Marvin, S. (2001) Splintering Urbanism Networked Infrastructures, Technological Mobilities and the Urban Condition, Roudledge Pub,. London and New York, ISBN 0-415-18965-9.

Günay, Z. Koramaz, K., Ozuekren, S. (2015) From squatter upgrading to large-scale renewal programmes: housing renewal in Turkey, Renewing Europe's Housing 2015, 215-244. 
Gümüşbağ, B. (2009) Katılım Ekseninde Kentsel Dönüşüm: Altındağ Aktaş Mahallesi Örneği (Urban Renewal on the Axis of Participation: The Example of Altındağ Aktaş District), Unpublished Msc Thesis, Ankara Üniv. Sosyal Bil. Enst., Ankara (in Turkish).

Gür, S., Türk, Ş. Ş. (2014). 6306 Sayılı Kanunla Yeniden Ortaya Çıkan Bina Ölçeğinde Kentsel Yenileme Pratiği: Bağcılar İlçesi Örneği (Urban Renewal Practice at the Scale of Buildings Reappeared with the Law No. 6306: The Case of Bağcılar District), 38. Dünya Şehircilik Günü Kolokyumu (s. 623-650), İstanbul: TMMOB Şehir Plancıları Odası, (in Turkish).

Güzey, O. (2016) The last round in restructuring the city: Urban regeneration becomes a state policy of disaster prevention in Turkey, Cities, 50, 40-53.

Ha, S. K. (2001) Developing a community-based approach to urban redevelopment, GeoJournal, 53, 39-45.

Ha, S.K. (2004) New shantytowns and the urban marginalized in Seoul Metropolitan Region, Habitat International, 28 (1), 123-141.

Hamidi,S., Zandiatashbar, A. (2021) Compact development and adherence to stay-at-home order during the COVID-19 pandemic: A longitudinal investigation in the United States, Landscape and Urban Planning, 103952

Heller, M., Hill, R. (2008) Land assembly districts, Harward Law Review, 121(6), 1465-1527.

Health, T. (2001) Adaptive re-use of offices for residential use: The experiences of London and Toronto, Cities, 18 (3), 173-184.

Home, R. (2007) Land readjustment as a method development land assembly, Town Planning Review, 78 (4), 459-484.

Ho, D.C.W., Yau, Y., Poon, S.W.,Liusman, E. (2012) Achieving Sustainable Urban Renewal in Hong Kong: Strategy for Dilapidation Assessment of High Rises, Journal of Urban Planning and Development 138(2),153-165.

Hong, Y. H. (2007). Assembling land for urban development: Issues and Opportunities. In Yu-Hung Hong and B. Needham (Eds.), Analyzing land readjustment: Economics, law, and collective action, 3-36, Lincoln Institute of Land Policy, Cambridge, Massachusetts.

Hong, Y., Needham, B. (2007) Analyzing land readjustment: economics, law and collective action (pp. 115134). Cambridge, USA: Lincoln Institute of Land Policy.

Ingram, G. K., Hong, Y.H. (Ed.), (2012). Value Capture and Land Policies. 6. Annual Land Policy Conference. Lincoln Institute of Land Policy

Jacobs, H.M., Bassett, E.M. (2011) All Sound, No Fury? The Impacts of State-based Kelo Laws, Planning and Environmental Law, 63.2, p.3-8.

Karaman, O. (2013) Urban renewal in Istanbul: reconfigured spaces, robotic lives, International Journal of Urban and Regional Research, 37(2), 715-733.

Kısar Koramaz,E., Koramaz, K., Özer, Ö. (2018) Urban transformation through property-led regeneration: A case of building renewals in Istanbul, ITU A/Z , 15 (2), 183-196.

Korthals Altes, W.K. (2007) The impact of abolishing social-housing grants on the compact-city policy of Dutch municipalities, Environment and Planning A 39 (6), 1497-1512.

Korthals Altes, W.K. (2014) Taking planning seriously: Compulsory purchase for urban planning in the Netherlands, Cities, 41,71-80.

Korthals Altes, W.K. (2016) Forced relocation and tenancy law in Europe, Cities, 52, p. 79-85.

Kürşat, Z. (2013). 6306 Sayılı Afet Riski Altındaki Alanların Dönüştürülmesi Hakkında Kanunun Özel Hukuk Alanındaki Etkileri. M. Yasin, \& C. Şahin içinde, Kentsel Dönüşüm Hukuku (s. 19-48). İstanbul: İstanbul Üniversitesi S.S. ONAR İdare Hukuku ve İlimleri Araştırma ve Uygulama Merkezi Yayınları.

Kuyucu, T. (2013) Law, Property and ambiguity: The uses and abuses of legal ambiguity in remaking Istanbul's informal settlements, International Journal of Urban and Regional Research, DOI: 10.111/14682427.12026.

Kuyucu, T. (2018) Türkiye'de kentsel dönüşümün dönüşümü: hukuki ve kurumsal çatışmalar üzerinden bir açıklama denemesi (The Transformation of urban transformation in Turkey: An institutional analysis), Idealkent, 24 (9), 364-386 (in Turkish).

Kuyucu, T., Unsal, O. (2010) 'Urban Transformation' as State-led Property Transfer: An Analysis of Two Cases of Urban Renewal in Istanbul. Urban Studies, 47(7), 1479-1499.

Islam, T., Enlil, Z. (2010) 5366 Sayılı Yasa Merkezli Dönüşüm ve Sulukula Örneği: Belediye’nin Hedefleri ve Yaşanan Gerçeklik (Law-Centered Transformation No. 5366 and the Example of Sulukule: The Goals of the Municipality and the Living Reality) D. Özdemir (Ed.) Kentsel Dönüşümde Politika, Mevzuat, Uygulama, Ankara: Nobel Yayın. p. 317-334 (in Turkish) 
Larbi, W.O., Antwi, A., Olomolaiye,P (2004) Compulsory land acquisition in Ghana-policy and praxis,Land Use Policy, Land Use Policy 21(2),115-127.

Lees, L., Shin, H.B., Lopez-Morales, E. (2015) Global Gentrifications: Uneven Development and Displacement, Policy Press, Bristol.

Lees, L., Slater,T. , Wyly,E. (2010) The Gentrification Reader, Routledge: London.

Lehavi, A., Licht, A. (2007) Eminent domain, Columbia Law Review, 107, 1704-1748.

Louw, E (2008) Land assembly for urban transformation: the case of 's Hertogenbosch in the Netherlands. Land Use Policy 25(1), 69-80.

Mathur, S. (2013) Self-financing Urbanization: Insights from the Use of Town Planning Schemes in Ahmadabad, India. Cities 31:308-316.

Miceli, T.J. and C.F. Sirmans (2007) The holdout problem, urban sprawl and eminent domain, Journal of Housing Economics 16, 309-19.

Moss, T. (2008) 'Cold spots' of Urban Infrastructure: 'Shrinking' Processes in Eastern Germany and the Modern Infrastructural Ideal, International Journal of Urban and Regional Research, 2008, 32 (2), 436 451.

Murie, A., Musterd, S. (2004) Social exclusion and opportunity structures in European cities and neighbourhoods, Urban studies 41 (8), p.1441-1459.

Murphy, K. (2012) The social pillar of sustainable development: A literature review and framework for policy analysis, Sustainability: Science, Practice, \& Policy, 8(1), 15-29.

Ocakçı, M., Türk, Ş.Ş., Terzi F. (2017) Kentsel Dönüşüm Uygulamalarında Planlama IIlke ve Kriterleri (Planning Principles and Criteria in Urban Renewal Practices), Birsen Yayınevi, ISBN: 9789755116709, (in Turkish).

Ozkan H.A, Turk S.S. (2016) Emergence, formation and outcomes of flexibility in Turkish planning practice, International Development Planning Review (IDPR), 38 (1), s. 25-54.

Özcivan, K. (2016) Kentsel Dönüşüm Alanlarındaki Farklı Hak Sahiplerinin Uzlaşma Eğilimleri: Gaziosmanpaşa IIlçesi Sarıgöl ve Yenidoğan Mahalleleri (Negotiation Practices of Different Rights Holders in Urban Renewal Areas: Gaziosmanpaşa District Sarıgöl and Yenidogan Neighborhoods), Unpublished Msc Thesis, Istanbul Technical University, Istanbul (in Turkish)

Özden, P.P. (2016) Kentsel Yenileme (Urban Renewal), $2^{\text {nd }}$ Editon, Imge Pub, Ankara (in Turkish).

Özsunay, E. (2015) 6306 Sayılı Kanun ve Kentsel Dönüşüm Uygulamalarına iliş̧kin Düşünceler (Thoughts on Law No. 6306 and Urban Renewal Practices), Istanbul: Vedat Kitapçlık (in Turkish).

Parés, M., Marti-Costa, M., Blanco, I. (2014) Geographies of Governance: How Place Matters in Urban Regeneration Policies, Urban Studies, 51(15), 3250-3267

Peck, J., Tickell, A. (2002) Neoliberalising space, Antipode, 34, 380-404.

Shin, H. B. (2009) Property-based redevelopment and gentrification: the case of Seoul, South Korea Geoforum, 40 (5), p. 906-917.

Shin, H.B. (2017) Property-based redevelopment and gentrification: The case of Seoul, South Korea, Geoforum, 40(5), 906-917.

Spaans, M., Janssen-Jansen, L., M. Van Der Veen (2011) Market-oriented compensation instruments: lessons for Dutch urban redevelopment, Town Planning Review, 82(4), 425-440.

Steen, M. (2004) Social exclusion and inner city Europe: regulating urban regeneration. Palgrave, Basingstoke,

Šumrada, R., Ferlan, M., Lisec, A. (2013) Acquisition and expropriation of real property for the public benefit in Slovenia, Land Use Policy, 32,14-22.

Şen, B., \& Öktem Ünsal, B. (2014) Derbent- Memeleketin Iş̧̧i Mahallesi ya da Küresel Kentin "Hukuksuz" Gecekondu Alanı (Derbent- The Workers' Quarter of the Hometown or the "Unlawful" Slum Area of the Global City), A. Türkün içinde, Mülk, Mahal, insan - İstanbul'da Kentsel Dönüşüm (s. 189-225). İstanbul: İstanbul Bilgi Üniversitesi Yayınları (in Turkish).

Şen, B., \& Türkmen, H. (2014) Başıbüyük- Bir Kentsel Dönüşüm Sınaması (Başıbüyük- An Urban Renewal Challenge), A. Türkün içinde, Mülk, Mahal, Insan - Istanbul'da Kentsel Dönüşüm (s. 143-188), İstanbul: İstanbul Bilgi Üniversitesi Yayınları, (in Turkish).

Tarakcı, S., Turk, S.S (2021a) Public value capturing in urban renewal: the fikirtepe case (Istanbul, Turkey), Journal of Housing and Built Environment, 1-31, DOI: 10.1007/s10901-021-09849-6.

Tarakçı and Turk, (2021 b, Fortcoming) Public Value Capture Capacity in the Urban Renewal Project Process: Fikirtepe Case, ICE Municipal Engineer,

Tarakçı, S.,Turk, S. S. (2019) Türkiye'de Kentsel Yenileme Projelerinde Artan Değerin Kazanımında Plan Notunun Kullanımı - Fikirtepe Örneğı. 4. Uluslararası Kent Araştırmaları Kongresi. Ankara

Tarakçı, S., Türk, Ş. Ş. (2020) Shaping of Flexibility in Urban Renewal Legal Sources in Turkey and Its Effect on Practices, ICONARP, 8 (2), 652-671. 
Tarakcı, S., Turk, S.S. (2015) Istanbul'da Deprem Riskinin Azaltilmasi Gerekçesine Dayali Kentsel Yenileme Uygulamalari (Urban Renewal Practices in Istanbul Due to Mitigation of the Risk of Earthquake), 8th National Earthquake Engineering Conference, May 11-14, 2015, Istanbul (in Turkish)

Torrance, M.I. (2008) Forging global governance? Urban infrastructures as Networked financial products? International Journal of Urban and Regional Research, 32.1, 1-21.

Turk, S. S., Korthals Altes, W. K. (2013) Some lessons from Turkish urban regeneration policy and practice, In: Michael Leary and John McCarthy (Eds.), Companion to Urban Regeneration, Routledge pub., 383-392. 978-0-415-53904-3.

Turk, S.S. (2014) Land Readjustment Experience in Turkey, Urban Legal Case Studies, Volume 3, UN-Habitat, United Nations Human Settlements Programme 2014, ISBN Number (Volume): 978-92-1-132637-6.

Turk, S.S. (2018) Comparison of the impacts of non-negotiable and negotiable developer obligations in Turkey, Habitat International, 75, 122-130.

Turk, S.S., Demircioğlu, E. (2013) Using of market-led measures for land assembly in Turkey, Habitat International, Vol. 40, 2013, pp. 201-210

Turk, S.S., Korthals Altes, W.K. (2010) How suitable is LR for renewal of inner city areas? An analysis for Turkey, Cities, Vol. 27, Issue 5, pp. 226-336.

Turk, S.S., Ozcivan, K. (2017) Negotiation Processes in Urban Renewal Projects in Turkey:The SarigölGaziosmanpaşa Case, ENHR, Albania, Tiran, 4 September 2017.

Turk, S.S., Tarakcl, S., Gürsoy, N. (2020) A large-scale urban renewal project in a vicious cycle of commons and anticommons: The Fikirtepe case (Istanbul, Turkey), Habitat International, 102, 102209.

Türkün A. (2014) Mülk, mahal, insan: İstanbul'da kentsel dönüşüm (Property, place, people: Urban transformation in Istanbul) İstanbul: Bilgi Üniversitesi Yayınları, 79-139 (in Turkish).

Türkün, A., Sarioglu, A. (2014) Tarlabaşı: Tarihî Kent Merkezinde Yoksulluk veDışlanan Kesimler Üzerinden Yeni Bir Tarih Yazılıyor (Tarlabaşı: A New History Is Written on Poverty and Excluded Sections in the Historical City Center) , A. Türkün (Ed.), In: Mülk, mahal, insan: İstanbul'da kentsel dönüşüm, İstanbul: Bilgi Üniversitesi Yayınları, 267-307 (in Turkish).

Türkün,A., Öktem Ünsal, B (2014) Tozkoparan: bir sosyal mesken alanının tasfiyesi (Tozkoparan: clearance of a social housing area) A. Türkün içinde, Mülk, Mahal, Insan - İstanbul'da Kentsel Dönüşüm (s. 311-348). İstanbul: İstanbul Bilgi Üniversitesi Yayınları

Unsal, F., Turk, S.S. (2014) Legal and institutional context of urban planning and urban renewal in Turkey: Thinking on Istanbul. Eds. G.Erkut ve M.R. Shrazi, The Case of Beyoğlu, Istanbul Dimensions of Urban Redevelopment, p.15-30.

URL-1, https://www.hurriyet.com.tr/ekonomi/emlak/8-yilda-610-bin-konut-kentsel-donusum-icin-yikildi41452458.

Van de Krabben, E., Needham, B. (2008) Land readjustment for value capturing: A new planning tool for urban redevelopment, Town Planning Review, 79,16, 651-672.

Van Straalen, F.M., Korthals Altes, W.K.(2016) Compulsory purchase for biodiversity conservation in the Netherlands, Land Use Policy, 38, p. 223-232.

Verhage, R. (2005) Renewing urban renewal in France, the UK and the Netherlands: Introduction, Journal of Housing and Built Environment, 20, 215-227.

Wang, H., Shen, Q., Tang, B., Lu, C., Peng, Y., Tang, L.(2014) A framework of decision-making factors and supporting information for facilitating sustainable site planning in urban renewal projects, Cities,40, 4455.

Webber, C., Marshall, A. (2007) Bridging the gap: Delivering infrastructure investment in Britain's cities, Journal of Urban Regeneration and Renewal, 1, p.7-21.

Zheng, W.Z., Shen, G.O., Wang, H. (2014) A review of recent studies on sustainable urban renewal, Habitat International, 41, 272-279.

\section{Resume}

Prof. Dr. Sevkiye Sence Turk is a faculty member at Istanbul Technical University, Faculty of Architecture, Department of Urban and Regional Planning. Her research interests focus on the legal and administrative problems of urban areas, land development processes in urban and urban development areas, urban renewal and location theory. She has articles published in recognized and respected journals on these subjects, international books and book chapters. The book titled 'Land Readjustment Experience in Turkey' was published by UN-Habitat in 2014. The chapter titled "Could Land Readjustment be participatory and inclusive in Turkey?" was published in the book "Global Experiences in Land Readjustment" by UN-Habitat in 2018. 